\title{
"The role of moderating audit quality relationship between corporate characteristics and financial distress in the Indonesian mining sector"
}

\begin{tabular}{|c|c|}
\hline AUTHORS & $\begin{array}{l}\text { Perdana Wahyu Santosa (D https://orcid.org/0000-0002-0221-3910 } \\
\text { Martua Eliakim Tambunan (D https://orcid.org/0000-0001-8715-4659 } \\
\text { Eva Rohima Kumullah }\end{array}$ \\
\hline ARTICLE INFO & $\begin{array}{l}\text { Perdana Wahyu Santosa, Martua Eliakim Tambunan and Eva Rohima Kumullah } \\
\text { (2020). The role of moderating audit quality relationship between corporate } \\
\text { characteristics and financial distress in the Indonesian mining sector. Investment } \\
\text { Management and Financial Innovations, 17(2), 88-100. } \\
\text { doi:10.21511/imfi.17(2).2020.08 }\end{array}$ \\
\hline DOI & http://dx.doi.org/10.21511/imfi.17(2).2020.08 \\
\hline RELEASED ON & Monday, 18 May 2020 \\
\hline RECEIVED ON & Friday, 07 February 2020 \\
\hline ACCEPTED ON & Tuesday, 05 May 2020 \\
\hline LICENSE & $\begin{array}{l}(c) \text { EY } \\
\text { This work is licensed under a Creative Commons Attribution } 4.0 \text { International } \\
\text { License }\end{array}$ \\
\hline JOURNAL & "Investment Management and Financial Innovations" \\
\hline ISSN PRINT & $1810-4967$ \\
\hline ISSN ONLINE & $1812-9358$ \\
\hline PUBLISHER & LLC "Consulting Publishing Company "Business Perspectives" \\
\hline FOUNDER & LLC "Consulting Publishing Company "Business Perspectives" \\
\hline
\end{tabular}

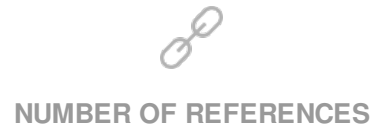

51

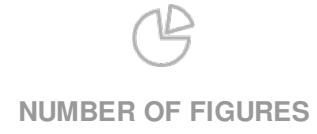

0
NUMBER OF TABLES

4

(C) The author(s) 2023. This publication is an open access article. 


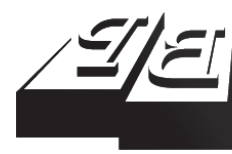

\section{BUSINESS PERSPECTIVES}

LLC "CPC "Business Perspectives" Hryhorii Skovoroda lane, 10, Sumy, 40022, Ukraine www.businessperspectives.org

Received on: $7^{\text {th }}$ of February, 2020 Accepted on: $5^{\text {th }}$ of May, 2020 Published on: $18^{\text {th }}$ of May, 2020
(C) Perdana Wahyu Santosa, Martua Eliakim Tambunan, Eva Rohima Kumullah, 2020

Dr. Perdana Wahyu Santosa, Maste of Management, YARSI University, Indonesia. (Corresponding author)

Martua Eliakim Tambunan, Ph.D., Master of Management, Christian University of Indonesia, Indonesia.

Eva Rohima Kumullah, PT Daya Mitra Sarana (Waskita Karya Group), Indonesia.
Perdana Wahyu Santosa (Indonesia), Martua Eliakim Tambunan (Indonesia), Eva Rohima Kumullah (Indonesia)

\begin{abstract}
Financial performance and corporate governance play an important role in financial distress in the mining sector, which is one of the most significant contributors to the Indonesian economy. This study aims to analyze the effect of corporate characteristics on financial distress (FD), which is moderated by corporate governance (audit quality), and uses the controlling variables (inflation rate and GDP). The study uses data from audited financial statements from mining sector in the Indonesia Stock Exchange for the period 2013-2018. Since the dependent variable (FD) is dichotomous, this study used a binary logistic regression model, as it is the case in many studies regarding the probability of bankruptcy filing. In line with the current study and some previous studies, leverage, efficiency (activity), market-to-book value, audit quality, and GDP affect the probability of financial distress significantly. Only liquidity and inflation do not impact FD. Besides, the moderating audit quality weakens the effect of liquidity and PBV; otherwise, it strengthens leverage and efficiency in predicting financial distress. As for managerial implications, this study concludes that corporate performance, corporate governance, and macro-risk factors affect the probability of financial distress. The authors suggest that mining firms need to pay attention to corporate governance and should watch the economic condition for business sustainability.
\end{abstract}

Keywords

financial distress, corporate characteristics, corporate governance, audit quality, macro-risk

JEL Classification

G30, G32, G33

\section{INTRODUCTION}

Mining sector is one of the high-risk sectors. It is characterized by turbulent business environment, especially in commodity prices fluctuation, social-political problems, and regulation stability (Vivekananda, Achsani, \& Maulana, 2019). The revenue of this sector mostly depends on global economy and Asian economic leaders like China, India, and Japan as the biggest markets for mining commodity (Haron, 2018). Indonesian mining sector must be supported by reliable and efficient players (companies) in developing their business under their respective commodities. Although the efficiency and financial performance of mining firms are essential to contribute to the creation of real value-added to stakeholders significantly, the corporate governance factors always play a critical role in these problems (Moreno-Bromberg \& Vo, 2017). The interplay between three factors, financial performance, corporate governance, and financial distress, is essential in mining firms because of the uncertainty of commodity prices, and regulation-political sentiments are relatively high (Jamaludin \& Hashim, 2017) 
Predicting corporate failure has become a long-standing problem in the study of corporate finance and credit risk. So far, researchers have relied on the Altman $z$-score model (1968), which uses accounting ratio-based information in determining how the probability of default is related to financial ratios (Waqas \& Md-Rus, 2018; Li \& Miu, 2010). The determinants that may affect the financial distress of mining firms were characterized by a negative profitability gap (NPG). This problem was caused by decreased revenue (sales) and increased operational costs significantly (Kasmiati \& Santosa, 2019; Purnanandam, 2008). The NPG caused negative net income, and it triggered the negative EPS. In this case, the company may have severe financial difficulty (Sayidah, Assagaf, \& Possumah, 2019). One of the next problems is liquidity starting to dry-up slowly but consistently. The decrease of liquidity, of course, triggered the increase of operational risk because the working capital of the firm will be destructive (Senbet \& Wang, 2012). In the next stage, solvency experienced interference, so management cannot fulfill long-term liabilities under third party commitments, especially investors and bondholders (Whitaker, 1999; Santosa, 2010).

In this study, another important factor is good corporate governance (GCG) that focuses on audit quality, which is a critical variable because of the auditor's potential to lose independence in giving a public opinion (Jostarndt \& Sautner, 2008; Senbet \& Wang, 2012). For this reason, this factor can moderate (strengthen or weaken) the influence of four factors, namely liquidity, solvency, profitability, and activity (Ananto, Mustika, \& Handayani, 2017). Audit quality based on reputation affiliated with the Big Four is considered to have a better reputation or have better professionalism and independence compared to other auditors. The Big Four have good perception in corporate governance and can provide high-quality audit services (Shahwan, 2015; Santosa, 2019).

A mining sector is an object of research because it had the most negative EPS value than other sectors in the previous year. This research aims to analyze the effect of the independent variables (profitability, liquidity, solvency, and efficiency) on the financial distress of the Indonesian mining firms. This research also analyzed the control variable such as gross domestic product, and inflation and moderating variable of audit quality in strengthening or weakening the influence of financial performance on financial distress. Therefore, the conclusions of this research are expected to contribute to stakeholders, especially shareholders and bondholders, to make financial decisions also to the top management.

\section{LITERATURE REVIEW}

Mining commodity represents the functional and highly critical role of the national economy of the emerging market, especially the countries that are based on natural resources - the process of valuing the national mining potential from a larger of expanding business development in this sector. During the period, under the emerging economy and the influence of new economic developments, the Indonesian mining sector has developed a substantial component of the gross domestic product (GDP) and created the trade flows in an efficient framework of business value chains (Sutomo, Wahyudi, \& Pangestuti, 2020). This sector is becoming a vital generator of wealth in the economy and storing value for domestic economic potential. To develop an efficient mining sector in Indonesia with high-level comparativeness and competitiveness requires regulation and diversification of commodity and futures exchange (Vivekananda, Achsani, \& Maulana, 2019).

According to corporate finance theory and most previous studies, the condition of financial difficulties, financial distress, liabilities payment default, and bankruptcy relates to financial characteristics and corporate governance (Whitaker, 1999; Jostarndt \& Sautner, 2008; Brédart, 2014). According to Kristanti and Herwany (2017) and Kumalasari, Hadiwidjojo, and Indrawati (2014), earnings per share (EPS) of the firm could indicate the companies that experience financial problems or financial distress. Companies that experience financial difficulties tend to have negative earnings per share (EPS). Some previous studies find that financial characteristics caused financial problems (Sayidah et al., 2019). 
Some researchers consider the relationship between financial characteristics such as liquidity, solvency, profitability, efficiency, and audit quality as mediating on financial distress in the mining sector. Hidayat and Meiranto (2014) state that liquidity has a positive effect in predicting financial distress, where the higher the liquidity, the better the performance of the company, and its EPS increases. Therefore, it will reduce the risk of a company experiencing financial distress. The high liquidity ratio shows that the company can meet its short-term obligations with current assets. This finding shows that the higher the liquidity ratio, the risk of the company experiencing financial distress will decrease. The high liquidity ratio shows that the company can meet its short-term obligations with current assets (Gitman \& Zutter, 2015).

Brîndescu-Olariu (2016) and Kristanti and Herwany (2017) stated that leverage (solvency) has a positive effect on financial distress. According to them, high leverage generates company risk, which also increases the possibility of financial distress, Brigham and Houston (2016) argued that this situation is because it occurs in its capital and may cover the total debt the company has, so that the capital owned by the company has guaranteed any liability to be borrowed (collateral). Ananto et al. (2017) and Kasmiati and Santosa (2019) stated that profitability has a negative effect on financial distress. The decrease in company profits weakens the company's ability to pay off both short-term and long-term liabilities. Santosa (2010), Sayidah et al. (2019), and Kumalasari et al. (2014) showed the same result that profitability affects financial distress negatively.

Santosa (2019) found that activity ratio affects the prediction of financial distress negatively. This finding was supported by Beaver, Correia, and McNichols (2010) who state that the activity ratio affects financial distress negatively. The measurement of the ratio of the company's efficiency can predict financial distress. Brealey, Myers, and Allen (2020) explain that corporate governance is a concept proposed for the sake of improving the company's performance through supervision or monitoring management performance and ensuring management accountability to stakeholders based on the regulatory framework. The concept of good corporate governance is proposed to achieve more transparent company management for all users of financial statements (Tirapat \& Nittayagasetwat, 1999; Prommin, Jumreornvong, Jiraporn, \& Tong, 2016).

\subsection{Hypotheses development \\ 1.1.1. Effect of liquidity on probability of financial distress}

Masdupi, Tasman, and Davista (2018) and Kumalasari et al. (2014) show that liquidity has a negative and significant influence on financial distress. In line with the above research, the results of research by Ayu, Handayani, and Topowijono (2017) also show that liquidity has a negative effect. Astuti and Pamudji (2015) stated that liquidity has a negative influence on the probability of financial distress. Companies that have large liquidity ratios will be less prone to financial distress (Brigham \& Houston, 2016). A different finding was offered by Hesty Erviani Zulaecha (2016) who stated that liquidity does not influence financial distress when management decides to add investment expenditure. So, from the description above, the hypothesis proposed is as follows:

\section{H1: Liquidity negatively influences the probabili- ty of financial distress. \\ 1.1.2. Effect of solvency on probability of financial distress}

Brîndescu-Olariu (2016) and Kristanti and Herwany (2017) stated that leverage (solvency, proxied by debt to equity ratio) has a positive effect on financial distress significantly because the higher leverage triggers the company's financial risk, especially the ability to cover its long-term liabilities. In line with the results of the study by Li and Miu (2010), solvency had a positive effect on financial distress. Senbet and Wang (2012) and Causholli and Knechel (2012) found similar findings that leverage (solvency) had a positive and significant effect on financial distress. In general, debt can increase value and reduce financial distress, but if the ratio of excess debt will increase the default risk for financial distress (Beaver et al., 2010; Santosa, 2019). However, Masdupi et al. (2018) found the negative relationship between leverage and financial distress. From the description above, the hypothesis made is as follows: 
H2: Solvency has a positive effect on probability of financial distress.

\subsubsection{Effect of market-to-book value on probability of financial distress}

Ananto, Mustika, and Handayani (2017) state that profitability has a negative and significant effect on financial distress. According to the results of research, Beaver et al. (2010) and Masdupi et al. (2018) showed the same results that profitability negatively affected financial distress. This finding explained that the decrease of corporate profits results in a decrease in the company's ability to pay off shortterm and long-term liabilities that trigger financial distress (Brigham \& Houston, 2016; Kamaluddin, Ishak, \& Mohammed, 2019; Altman, Hotchkiss, \& Wang, 2019). The hypothesis is as follows:

\section{H3: Market-to-book value has a positive effect on probability of financial distress.}

\subsubsection{Effect of efficiency on probability of financial distress}

Purnanandam (2008) and Prasetyo and Fachrurrozie (2016) found that the efficiency ratio (proxied by TATO) affects the prediction of financial distress negatively. The results of the study are in line with the findings of Hidayat and Meiranto (2014). If the company cannot utilize its assets efficiently in creating revenue (sales), then the company has difficulty in business competition. Decreased revenue causes a decrease in operating profit and net profit, and even companies are threatened to lose money or negative EPS (Beaver et al., 2010). This condition will trigger financial problems and continue to financial distress (Brigham \& Houston, 2016; Altman, Hotchkiss, \& Wang, 2019). So, from the explanation above, the hypothesis made is as follows:

\section{H4: Efficiency has a negative effect on probability of financial distress.}

\subsubsection{Effect of audit quality on probability of financial distress}

Audit quality has a significant effect on the control and supervision functions of management. With the increasing number of cases of fraud, the importance of implementing good corporate governance is increasingly being realized (Causholli \& Knechel, 2012). The audit quality can moderate (strengthen or weaken) the influence of four factors, namely, liquidity, solvency, profitability, and activity (Astuti \& Pamudji, 2015). Audit quality is based on CPA's reputation. CPA affiliated with Big Four is considered to have a better reputation or have good corporate governance and can provide high-quality audit services (Causholli \& Knechel, 2012).

H5: Audit quality has a negative effect on probability of financial distress.

\subsubsection{Effect of controlling variables on probability of financial distress}

To take the effect of main independent variables that may influence corporate filing into account, the model considers two control variables. Control variables are recorded on last fiscal year as it was the case for the independent variables. One controls for macro-risk of firm-related effects: inflation rate and GDP (Tinoco \& Wilson, 2013). Macro-risk factors show discriminant power regarding the decision to file for financial problems and bankruptcy (Kurniasanti \& Musdholifah, 2018; Tirapat \& Nittayagasetwat, 1999). Santosa (2019) state that inflation has a significant positive effect on financial difficulties, where the lower sensitivity to the inflation rate will inhibit financial problems in the company.

H6: Macro-risk (inflation rate and GDP) has a positive effect on probability of financial distress.

\subsubsection{Effect of moderation of audit quality on interaction with independent variables}

Causholli and Knechel (2012) and Ananto et al. (2017) found that corporate governance proxies (proxied by audit committee) affect the financial distress negatively. Thus, the higher audit quality will reduce the probability of financial distress in the normal financial performance conditions; however, the reinforced contagion effect of low audit quality may lead to financial distress.

Moreover, the effect of low audit quality persists over subsequent years for mining firms, and both the investment opportunity and financial distress reinforce the contagion effect of misstatement to 
future misstatement (Du \& Lai, 2018). Audit quality can moderate financial performance variables. Theoretically, the better the audit quality, the stronger the influence of moderation, and vice versa (Salleh \& Mara, 2019; Elloumi \& Gueyié, 2001). Tanyi and Smith (2015) state that the quality of audit committee and CPA force the corporation to comply with the corporate governance optimally.

H7: Audit quality mediates the effect of financial ratios on probability of financial distress.

\section{METHODS}

\subsection{Data collection and sources}

The data collection technique used in this research is a documentation technique, which is a collection of data by looking at, analyzing, and quoting written notes that have the allocation of research and other sources regarding issues that were studied by related agencies. The literature analysis consists of the collection of data, scientific works, software, and validation that have relevance to the problem under study. The sources of data are audited financial reports of the companies included in the mining sector index of the Indonesia Stock Exchange in the period 2013-2018. The annual financial reports are collected from the Indonesia Capital Market Institute-IDX, Bloomberg, Yahoo Finance, and company website.

\subsection{Population and samples}

The sample is part of the number and characteristics that are represented by the population. The sampling technique is a purposive sampling method, which is a method of determining the sample with specific considerations. This study has 27 samples matching the analysis criteria.

\subsection{Research variables and measurement scale}

The dependent variable in this study is Financial distress. While the independent variables are Profitability (Return on equity), Liquidity (Current ratio), Solvency (Debt to equity ratio), and Activity (Total assets turnover), the moderating variable is the Audit quality, and controlling variables are Inflation and GDP.
Table 1. Description of variables

\begin{tabular}{l|c|c}
\hline Variables & Description relationship & Notation \\
\hline $\begin{array}{l}\text { Financial } \\
\text { distress }\end{array}$ & Dummy; (1: EPS -; 0: otherwise) & FD \\
Audit quality & $\begin{array}{c}\text { Dummy; (1: big four; 0: otherwise) } \\
\text { Big Four: PwC, KPMG, Deloitte, and EY }\end{array}$ & AQL \\
\hdashline Inflation & Inflation rate & INF \\
\hdashline GDP & Ln Gross domestic product & GDP \\
\hdashline Liquidity & Current assets to current liabilities & LIQ \\
\hline Leverage & Total debt to equity & LEV \\
Market ratio & Price to book value & PBV \\
Activity & Revenue to total assets & ACT \\
\hline
\end{tabular}

\subsection{Logit regression specification}

The analysis method uses logistic regression models and formed based on some previous studies following equation (Jaafar, Muhamat, Alwi, Karim, \& Rahman, 2018; Gul, Khedmati, Lim, \& Navissi, 2018;; Lu \& Ma, 2016; Moreno-Bromberg \& Vo, 2017; Waqas \& Md-Rus, 2018a; Brédart, 2014; Opler \& Titman, 1994):

Model 1.

$\log \left(\frac{F D}{1-F D}\right)_{i t}=\alpha_{0}+\alpha_{1} L I Q_{i t}+\alpha_{2} L E V_{i t}+$

$+\alpha_{3} P B V_{i t}+\alpha_{4} A C T_{i t}+\alpha_{5} A Q L_{i t}+\varepsilon_{i t}$.

Model 2.

$\log \left(\frac{F D}{1-F D}\right)_{i t}=\beta_{0}+\beta_{1} L I Q_{i t}+\beta_{2} L E V_{i t}+$

$+\beta_{3} P B V_{i t}+\beta_{4} A C T_{i t}+\beta_{5} A Q L_{i t}+\beta_{6} I N F_{t}+$

$+\beta_{7} G D P_{t}+\varepsilon_{i t}$.

Model 3.

$\log \left(\frac{F D}{1-F D}\right)_{i t}=\delta_{0}+\delta_{1} L I Q_{i t}+\delta_{2} L E V_{i t}+$

$+\delta_{3} P B V t_{i t}+\delta_{4} A C T_{i t}+\delta_{5} A Q L_{i t}+$

$+\delta_{6} I N F_{t}+\delta_{7} G D P_{t}+\delta_{8}(L I Q \cdot A Q L)_{i t}+$

$+\delta_{9}(L E V \cdot A Q L)_{i t}+\delta_{10}(P B V \cdot A Q L)_{i t}+$

$+\delta_{11}(A C T \cdot A Q L)_{i t}+\varepsilon_{i t}$.

where $F D$ - financial distress, $L I Q$ - liquidity, $L E V$ - solvency, $P B V$ - profitability, $A C T$ activity (Asset turnover), $A Q L$ - audit quality, $I N F$ - inflation rate, GDP - Ln gross domestic product. 


\section{RESULTS}

\subsection{Descriptive analysis}

Table 2 presents descriptive statistics for the dependent variable, independent (explanatory) variables, moderating and controlling variables used in the model analysis. First, the mean and standard deviation of financial distress (FD) are 0.2833 and 0.4518 , respectively, in which the coefficient of variation is 1.5947. The mean of FD indicated that the mining firm with a financial problem is about 24 percent generally. The mean and standard deviation of liquidity is 1.8783 and 2.2273 , respectively. The coefficient of variation of liquidity is 1.1858 . The mean of leverage is 1.0970 , with a standard deviation of 1.5596 , and a coefficient of variation is 1.4216 . The mean of activity and market-to-book is 0.6140 and 1.4231 , and the coefficient of variation is 0.8172 and 1.3056, respectively. These findings indicate the data distribution is relatively small and tends to normal distribution. The mean of market-to-book is 1.4231, indicating positive future growth opportunity of the sample, and this is compared by the positive mean of gross domestic product (GDP), which is 9.1557 .

Table 2 shows the results of the descriptive analysis for measures of financial distress (FD), liquidity (LIQ), leverage-debt ratio (LEV), activity as efficiency ratio (ACT), moderating variable (audit quality (AQL)), and the controlling variables (inflation rate (INF) and gross domestic product (GDP)).

The mean and standard deviation of audit quality (AQL) are 0.5333 and 0.5002 , with the coefficient of variation is 0.94138 . This mean of audit quality, indicating a positive trend of the use of the CPA with the highest quality in the mining sector, was about 53 percent. This finding is proper to use audit quality as a moderating variable. Then, the means of inflation rate (INF) and gross domestic product (GDP) are 0.0497 and 9.1557, with the standard deviation being 0.0241 and 0.6311 , respectively. The coefficient of variation of GDP is very small of 0.0689 . This finding showed that the fluctuation of GDP is minimal and persistent.

\subsection{Correlation analysis}

Table 3 shows the Pearson correlation matrix (Spearman) for dependent, independent, moderating, and control variables in the main analysis at the lower (upper) diagonal. The correlation between financial distress (FD) with liquidity (LIQ), leverage (LEV) and market-to-book value (PBV) is positive, yet not economically large $(0.0628,0.0989$, and 0.0728 , respectively), which, according to Spearman correlation, are insignificant, highlighting the attention of controlling and moderating for others factors of financial distress, especially inflation rate, GDP, and audit quality. Besides, the correlation of FD with activity efficiency (ACT) and audit quality (AQL) for moderating variable is negative and significant, as indicated by the Pearson (Spearman) correlation of -0.4766 and -0.3014 , respectively.

For controlling variables, the inflation rate (INF) and GDP are insignificantly and positively and negatively correlated, as indicated by Spearman analysis of 0.0228 and -0.0473 , respectively. The problem of multicollinearity is not seemed to be a problem, given that the highest variance inflation factor (centered) (VIF) is under 10, pertinent to FD.

Table 2. Descriptive statistics

\begin{tabular}{|c|c|c|c|c|c|c|c|c|}
\hline Descriptive statistics & FD & LIQ & LEV & ACT & PBV & AQL & INF & GDP \\
\hline Mean & 0.2833 & 1.8783 & 1.0970 & 0.6140 & 1.4231 & 0.5333 & 0.0497 & 9.1557 \\
\hline Median & 0.0000 & 1.5400 & 0.7880 & 0.5175 & 0.8969 & 1.0000 & 0.0348 & 9.3898 \\
\hline Maximum & 1.0000 & 20.170 & 12.800 & 1.8680 & 12.271 & 1.0000 & 0.0838 & 9.6049 \\
\hline Minimum & 0.0000 & 0.0520 & -5.6630 & 0.0000 & -2.9756 & 0.0000 & 0.0302 & 7.7698 \\
\hline Std. Dev. & 0.4518 & 2.2273 & 1.5596 & 0.5018 & 1.8580 & 0.5002 & 0.0241 & 0.6311 \\
\hline Skewness & 0.9615 & 5.4545 & 3.1337 & 0.5777 & 2.8969 & -0.1336 & 0.6887 & -1.6683 \\
\hline Kurtosis & 1.9241 & 40.245 & 25.097 & 2.2908 & 14.274 & 1.0178 & 1.4995 & 3.9875 \\
\hline
\end{tabular}


Table 3. Correlation analysis

\begin{tabular}{|c|c|c|c|c|c|c|c|c|}
\hline Probability & FD & LIQ & LEV & ACT & PBV & $A Q L$ & INF & GDP \\
\hline \multirow{2}{*}{ FD } & 1.0000 & - & - & - & - & - & - & - \\
\hline & - & - & - & - & - & - & - & - \\
\hline \multirow{2}{*}{ LIQ } & 0.0628 & 1.0000 & - & - & - & - & - & - \\
\hline & 0.4020 & - & - & - & - & - & - & - \\
\hline \multirow{2}{*}{ LEV } & 0.0989 & -0.1405 & 1.0000 & - & - & - & - & - \\
\hline & 0.1861 & 0.0599 & - & - & - & - & - & - \\
\hline \multirow{2}{*}{ ACT } & -0.4766 & -0.0144 & -0.2890 & 1.0000 & - & - & - & - \\
\hline & 0.0000 & 0.8473 & 0.0001 & - & - & - & - & - \\
\hline \multirow{2}{*}{ PBV } & 0.0728 & 0.0435 & 0.0679 & 0.0776 & 1.0000 & - & - & - \\
\hline & 0.3313 & 0.5616 & 0.3647 & 0.3001 & - & - & - & - \\
\hline \multirow{2}{*}{ AQL } & -0.3014 & 0.0541 & -0.2336 & 0.3793 & 0.1856 & 1.0000 & - & - \\
\hline & 0.0000 & 0.4705 & 0.0016 & 0.0000 & 0.0126 & - & - & - \\
\hline \multirow{2}{*}{ INF } & 0.0228 & 0.0761 & -0.0253 & 0.1354 & 0.0037 & 0.0009 & 1.0000 & - \\
\hline & 0.7612 & 0.3096 & 0.7356 & 0.0699 & 0.9596 & 0.9990 & - & - \\
\hline \multirow{2}{*}{ GDP } & -0.0473 & -0.0899 & 0.0039 & -0.1262 & 0.0491 & -0.0264 & -0.7178 & 1.0000 \\
\hline & 0.5283 & 0.2298 & 0.9579 & 0.0912 & 0.5122 & 0.7248 & 0.0000 & - \\
\hline
\end{tabular}

\subsection{Logistic regression results}

In this sub-section, the authors briefly show the findings of the logistic model (logit); the results will be discussed in the next section. Table 4 presents the results of the logistic regression of three models. Three models were constructed and then tested depending on the variables included. The only moderating variable is analyzed in Model 3; the four main effect variables are liquidity, leverage, market-to-book, and activity efficiency included in Model 1, Model 2, and Model 3. This study used the controlling variables (inflation rate and GDP) as macro-risk factors added in Model 2 and Model 3, respectively.

Comparing those three models, the authors notice some interesting findings and improvements to discuss in the next section. Indeed, the Model 1 showed that the main dependent variables results are liquidity (+/insignificant); leverage (-/insignificant); activity-efficiency (-/significant); marketto-book value (+/significant), and audit quality (-/ significant). The independent variables (activity efficiency) and moderating variables are negative $(-3.5947$ and -0.8480 , respectively). The moderating variable audit quality shows a negative effect on probability of financial distress. Generally, the results of Model 1 are consistent with some previous studies on financial distress and bankruptcy.

After conducting the next logistic regression, Model 2 specification resulted in some improvements, especially in the number of main varia- bles that significantly correlated with the probability of financial distress. Model 2 initial results were consistent with some previous studies, which show that first liquidity negatively and insignificantly correlated with financial distress. These results were in line with Model 1 that liquidity does not affect financial distress. Secondly, leverage, activity efficiency, and market-to-book value are positively and significantly correlated with probability of financial distress of $-0.1928,-4.0647$, and 0.2454 , respectively. The moderating variable (audit quality) shows a negative effect on the probability of financial distress of -0.8673 , significant at $\alpha=5 \%$. The controlling variables (macro-risk) show that the inflation rate and GDP negatively correlated with financial distress of -0.9416 and 0.7923 , but the inflation rate has an insignificant effect. Generally, the results of Model 2 are consistent with some previous studies, except liquidity and inflation rate variables.

The final analysis of Model 3 that expanded moderating effect of audit quality on four main dependent variables presents similar results with Model 2, especially in four main dependent variables that liquidity does not affect probability financial distress and leverage (-), activity efficiency (-), and market-to-book value (+) of $-0.3015,-6.4421$, and 0.0855 , respectively. Leverage and activity are significant at $\alpha=5 \%$, and PBV at $\alpha=10 \%$. The moderating variable (audit quality) is significantly and negatively correlated with financial distress and macro-risk factors. GDP shows a similar result with audit quality that affects FD significantly 
Table 4. Logistic regression results

\begin{tabular}{|c|c|c|c|c|c|c|c|}
\hline \multirow{2}{*}{ Variables } & \multirow{2}{*}{ Predict } & \multicolumn{2}{|c|}{ Model 1} & \multicolumn{2}{|c|}{ Model 2} & \multicolumn{2}{|c|}{ Model 3} \\
\hline & & Coeff. & Sig. & Coeff. & Sig. & Coeff. & Sig. \\
\hline \multicolumn{8}{|c|}{ Independent } \\
\hline Liquidity & - & 0.0616 & 0.5471 & 0.0238 & 0.8026 & 0.0393 & 0.7617 \\
\hline Leverage & $+1-$ & -0.1633 & 0.1553 & -0.1928 & $0.0888^{* * *}$ & -0.3015 & $0.0216^{* *}$ \\
\hline Activity & - & -3.5947 & $0.0000 *$ & -4.0647 & $0.0000^{*}$ & -6.4421 & $0.0000 *$ \\
\hline Market value & + & 0.2108 & $0.0549 * * *$ & 0.2454 & $0.0300 * *$ & 0.0855 & $0.0618^{* * *}$ \\
\hline \multicolumn{8}{|c|}{ Mediating } \\
\hline Audit quality & - & -0.8480 & $0.0492^{* *}$ & -0.8673 & $0.0478^{* *}$ & -3.2279 & $0.0082^{*}$ \\
\hline \multicolumn{8}{|c|}{ Controlling } \\
\hline Inflation & + & & & -0.9416 & 0.9415 & -3.2051 & 0.8139 \\
\hline GDP & + & & & -0.7923 & $0.0970^{* * *}$ & -0.8971 & $0.0790^{* * *}$ \\
\hline LIQAQL & & & & & & 0.0038 & 0.9910 \\
\hline LEV.AQL & & & & & & 0.7508 & $0.0919 * * *$ \\
\hline$A C T \cdot A Q L$ & & & & & & -3.9192 & $0.0295^{* *}$ \\
\hline $\mathrm{PBV} \cdot \mathrm{AQL}$ & & & & & & 0.1739 & 0.4604 \\
\hline C & & 0.8303 & 0.0491 & 8.3575 & 0.09563 & 10.37295 & 0.0513 \\
\hline McFadden $R^{2}$ & & 0.3109 & & 0.2875 & & 0.3487 & \\
\hline Akaike criterion & & 0.9159 & & 0.9103 & & 0.9097 & \\
\hline
\end{tabular}

Note: *significant at $\alpha=1 \%, * *$ significant at $\alpha=5 \%$, and $* * *$ significant at $\alpha=10 \%$. Method: $\mathrm{ML}-$ binary logit (NewtonRaphson/Marquardt steps); The dependent variable is financial distress (FD): binary logit 1/0; main independent variables are liquidity (current ratio), leverage (debt-to-equity ratio), activity efficiency assets (assets turnover) and market-to-book value (price-to-book). Controlling variables are macro-risk factors: inflation rate and GDP, and the moderating is audit quality (dummy 1/0: Big Four CPA). Model 1: logistic regression with the main dependent variables plus moderating variable; Model 2: the extension of Model 1, adding by controlling variables (macro-risk); and Model 3: expanding Model 2, adding by moderating effect on four main variables.

(-); however, the inflation rate does not affect. The audit quality as an independent variable showed a negative influence with the coefficient of -3.2279 and significant at $\alpha=1 \%$. The tendency of a negative effect of audit quality is a good sign for corporate governance in the mining sector.

The audit quality as a moderating variable that interacted with the main independent variables showed the strength or weakness of the effect on the correlation between liquidity, leverage, efficiency, and market-to-book value and probability of financial distress. Model 3 in Table 4 presents the interaction between liquidity and audit quality (LIQ.AQL), with a coefficient of 0.0038 and insignificance. Then goes the interaction between leverage and audit quality (LEV.AQL), with a coefficient of 0.7508 and significance at $\alpha=10 \%$ (the correlation before the moderating is negative). This result means strengthening and turning off the correlation between leverage and financial distress. The authors also noticed that the interaction between efficiency and audit quality (ACT.AQL) is similar to the interaction between leverage and audit quality. The interaction between leverage and audit quality audit with a coefficient of -3.9292 significant at $\alpha=5 \%$ means that the audit quality was strengthening the correlation between activity ratio and financial distress. However, the interaction effect of market-to-book value and audit quality (PBV.AQL) is insignificant; it means the mediator variable is weakening the PBV effect on the probability of financial distress.

\section{DISCUSSION}

This study contributes to financial distress and corporate governance literature by examining the corporate characteristics, and controlling variable macro-risk role of probability of financial distress. The authors also examined the differences in the interaction impact of moderating (audit quality) with each corporate characteristic variable through a logit model. The study results were classified in three models that indicate that the main independent variables in Model 1, such as efficiency ratio (-), market-to-book value (+), and audit quality (-), are significantly correlated with financial distress. These findings are supported by some previous empirical studies (Kristanti \& Herwany, 2017; Beaver et al., 2010; Tanyi \& Smith, 2015; Rahmat, Iskandar, \& Saleh, 2009). 
The contrast in Model 2 that included the controlling variables, inflation rate, and GDP in a logit regression, the number of main variables that affect the probability of financial distress increased. The leverage (-), efficiency (-), market-tobook value (+), and audit quality (-) affect financial distress significantly. These results support this hypothesis (prediction). Demonstrating the controlling variables as macro-risk issues could increase the accuracy of the prediction model, the results of the analysis contribute to the literature regarding financial problem detection. The results of Model 2 are in line with some findings of previous empirical studies (Opler \& Titman, 1994; Waqas \& Md-Rus, 2018b; Brédart, 2014; Lu \& Ma, 2016). The controlling variables (macro-risk factors, inflation rate, and GDP) affect the difference result that GDP is negatively correlated to financial distress in line with prediction, but the other variable (inflation) does not affect financial problems. According to economic theory, the increase of GDP growth may have raised their demand and the price of mining commodity. These results are also supported by Kurniasanti and Musdholifah (2018), Pranowo et al. (2010).

Model 3, which shows the interaction between moderating variable (audit quality) and all variables in this study, presents some interesting findings. The evidence that included the moderating audit quality is similar to Model 2 results, where the leverage (-), efficiency (-), market-to-book value (+), and audit quality itself (as independent) showed significant correlation with financial dis- tress. Besides, the controlling variables (inflation rate and GDP) showed similar results that inflation rate does not impact financial problems directly; otherwise, GDP has a significant effect. These findings are in line with some previous studies (Tinoco \& Wilson, 2013; Sayidah et al., 2019; Salleh \& Mara, 2019; Soebyakto, Mukhtaruddin, Relasari, \& Sinulingga, 2018; Kumalasari et al., 2014).

Moreover, audit quality as a moderating variable may affect the interaction with four main independent variables: liquidity, leverage, efficiency, and PBV. Interaction liquidity and audit quality, and PBV and audit quality do not affect financial distress, which means that the moderating variable (audit quality) weakens the relationship between liquidity and PBV and financial distress. The interaction between the leverage (debt ratio) presented a positive effect on financial distress and turned off the sign of coefficient from negative to positive, which means audit quality may have changed the leverage in line with earlier prediction (Pranowo et al., 2010; Beaver et al., 2010). So, the larger the debt ratio of the mining firm, the higher the probability of financial distress and bankruptcy. The interaction between efficiency (total assets turnover) and audit quality showed a negative impact on financial distress, which means the moderating variable strengthens the correlation between them. More efficiency of mining management with good quality of audit may impact the decreasing probability of financial distress ( $\mathrm{Lu} \&$ Ma, 2016; Vo, Pham, Ho, \& McAleer, 2019).

\section{CONCLUSION}

The study examines the impact of information ratios in financial statements on probability of financial distress. The results and discussion of the first logit model, which used corporate characteristics, only state that the efficiency, market-to-book value, audit quality are determinants that have a positive/negative effect on probability of financial distress. In contrast, the liquidity and leverage do not impact on the financial problems. However, when using the second logit model that used controlling variables of macroeconomic factors such as inflation rate and GDP, the results are not the same. The research results found that leverage, efficiency, market-to-book value, audit quality, and GDP significantly correlated with financial distress, but liquidity and inflation rate did not. The model with controlling variables is more appropriate compared to the previous one because it included macro-risk factors.

The third logit model presents more realistic results, in which the authors included the impact of moderating variable (audit quality) in the interaction with four main independent variables. The evidence that included the moderating variable (audit quality) is similar to the second model results that the leverage 
$(-)$, efficiency (-), market-to-book value (+), and audit quality itself (as an independent variable) showed the significant correlation with financial distress. Besides, the controlling variables (inflation rate and GDP) showed similar results that the inflation rate does not impact financial problems directly; otherwise, GDP has a significant effect. The interaction between moderating variable (audit quality) and four main variables in this study presents some interesting findings. The interaction between liquidity and audit quality does not affect financial distress, as well as the interaction of PBV and audit quality, which means that the moderating variable (audit quality) weakens the relationship between liquidity and PBV with a financial problem.

The interaction between the leverage (debt ratio) and audit quality presented a positive effect on financial distress. It turned off the sign of coefficient from negative to be positive, which means audit quality may have changed the leverage in line with earlier prediction. So, the larger the debt ratio of the mining firm, the higher the probability of financial distress and bankruptcy. The interaction between efficiency (total assets turnover) and audit quality showed a negative impact on financial distress, which means the moderating variable strengthens the correlation between them. More efficiency of mining management with good audit quality may impact the decreasing probability of financial distress.

\section{Managerial implications}

Firstly, this research contributed to the literature on the inclusion of corporate governance as the moderating variable and enabled to improve the financial distress prediction model. Better audit quality can improve better information to reveal financial distress. The most important thing in financial distress is leverage or capital structure that more debt can escalate financial distress. This research shows that audit quality can explain more clearly financial distress caused by leverage.

Secondly, for managers and stakeholders, this study concludes that corporate performance, corporate governance, and macro-risk factors affect the probability of financial distress. The authors state that mining firms need to pay attention to corporate governance, especially audit quality, and should watch the economic condition. The combination of corporate governance from audit quality and corporate performance can increase the predictability of financial distress. It implies that corporate governance should be an integral part of corporate financial action, especially implementing transparency principles for good quality of information.

Thirdly, this empirical study may help shareholders establish corporate governance mechanisms to prevent financial distress or to decide their investment choices in Indonesian mining firms. Good audit quality can prevent a shareholder from receiving asymmetrical information. It means that shareholders can make a decision better with the financial information that has been audited with the qualified independent auditor.

\section{Limitations and avenue for future research}

This study has some limitations. Firstly, it would have been better to include more precise variables, especially the main independent and controlling internal variables. Secondly, this study needs more accurate information regarding the reputation of the shareholder and management credibility reasons for compliance of corporate governance of the sample of firms. Further studies may use a complete dataset, including a more extended period and more detailed information regarding the financial, stripping ratio, and financial difficulties that lead these firms to file for bankruptcy. 


\section{ACKNOWLEDGEMENT}

Many thanks to the editor(s) and anonymous referee/reviewers for valuable inputs and feedback.

\section{AUTHOR CONTRIBUTIONS}

Conceptualization: Perdana Wahyu Santosa, Martua Eliakim Tambunan.

Data curation: Eva Rohima Kumullah.

Formal analysis: Perdana Wahyu Santosa, Eva Rohima Kumullah.

Funding acquisition: Perdana Wahyu Santosa, Martua Eliakim Tambunan.

Investigation: Eva Rohima Kumullah.

Methodology: Perdana Wahyu Santosa, Martua Eliakim Tambunan, Eva Rohima Kumullah.

Resources: Perdana Wahyu Santosa, Martua Eliakim Tambunan.

Software: Eva Rohima Kumullah.

Supervision: Perdana Wahyu Santosa, Martua Eliakim Tambunan.

Validation: Martua Eliakim Tambunan, Eva Rohima Kumullah.

Writing - original draft: Perdana Wahyu Santosa, Martua Eliakim Tambunan.

Writing - review \& editing: Perdana Wahyu Santosa.

\section{REFERENCES}

1. Altman, E. I., Hotchkiss, E., \& Wang, W. (2019). Corporate Financial Distress, Restructuring, and Bankruptcy. In Corporate Financial Distress, Restructuring, and Bankruptcy (4th ed.). https:// doi.org/10.1002/9781119541929

2. Ananto, R. P., Mustika, R., \& Handayani, D. (2017). Pengaruh Good Corporate Governance (GCG), Leverage, Profitabilitas dan Ukuran Perusahaan Terhadap Financial Distress Pada Perusahaan Barang Konsumsi Yang Terdaftar Di Bursa Efek Indonesia. Jurnal Ekonomi \& Bisnis Dharma Andalas, 19(1), 92-105. Retrieved from http://ojs. unidha.ac.id/index.php/edb_dharmaandalas/article/view/51

3. Astuti, P., \& Pamudji, S. (2015). Analisis Pengaruh Opini Going Concern, Likuiditas, Solvabilitas, Arus Kas, Umur Perusahaan dan Ukuran Perusahaan terhadap kemungkinan Financial Distress. Diponegoro Journal of Accounting, 4(1), 1-11. Retrieved from https://ejournal3.undip.ac.id/ index.php/accounting/article/ view/15077/14573

4. Ayu, A., Handayani, S., \& Topowijono, T. (2017). Pengaruh Likuiditas, Leverage, Profitabilitas, dan Ukuran Perusahaan terhadap Financial Distress: Studi pada Perusahaan Manufaktur Sektor Industri Dasar dan Kimia di Bursa Efek Indonesia. Jurnal Administrasi Bisnis S1 Universitas Brawijaya, 43(1), 138-147.

5. Beaver, W. H., Correia, M., \& McNichols, M. F. (2010). Financial statement analysis and the prediction of financial distress. Foundations and Trends in Accounting, 5(2), 99-173. https:// doi.org/10.1561/1400000018

6. Brealey, R. A., Myers, S. C., \& Allen, F. (2020). Principles of Corporate Finance (13th ed.). New York: McGraw-Hill/Irwin.

7. Brédart, X. (2014). Financial Distress and Corporate Governance: The Impact of Board Configuration. International Business Research, 7(3), 7280. https://doi.org/10.5539/ibr. v7n3p72

8. Brigham, E. F., \& Houston, J. F. (2016). Fundamentals of Financial Management (14th ed.). New York: Cengage.

9. Brîndescu-Olariu, D. (2016). Bankruptcy prediction based on the debt ratio. Theoretical and Applied Economics, XXIII(2), 145-
156. Retrieved from http://store. ectap.ro/articole/1188.pdf

10. Causholli, M., \& Knechel, R. (2012). Lending relationships, auditor quality and debt costs. Managerial Auditing Journal, 27(6), 550-572. https://doi. org/10.1108/02686901211236391

11. Du, X., \& Lai, S. (2018). Financial Distress, Investment Opportunity, and the Contagion Effect of Low Audit Quality: Evidence from China. Journal of Business Ethics, 147(3), 565-593. https://doi. org/10.1007/s10551-015-2986-5

12. Elloumi, F., \& Gueyié, J. P. (2001). Financial distress and corporate governance: An empirical analysis. Corporate Governance: The International Journal of Business in Society. https://doi. org/10.1108/14720700110389548

13. Gitman, L. J., \& Zutter, C. J. (2015). Principles of Managerial Finance (14th ed.). Singapore: Pearson Education.

14. Gul, F. A., Khedmati, M., Lim, E. K. Y., \& Navissi, F. (2018) Managerial ability, financial distress, and audit fees. Accounting Horizons, 32(1), 29-51. https://doi. org/10.2308/acch-51888

15. Haron, R. (2018). Firm level, ownership concentration and 
industry level determinants of capital structure in an emerging market: Indonesia evidence. Asian Academy of Management Journal of Accounting and Finance, 14(1), 127-151. https://doi.org/10.21315/ aamjaf2018.14.1.6

16. Hesty Erviani Zulaecha, A. M. (2016). Pengaruh likuiditas, leverage, dan sales growth terhadap financial distress. Jurnal Manajemen Bisnis, 4(1), 107-115. Retrieved from http://jurnal. umt.ac.id/index.php/jmb/article/ view/1573

17. Hidayat, M. A., \& Meiranto, W. (2014). Prediksi Financial Distress Perusahaan Manufaktur di Indonesia. Diponegoro Journal of Accounting, 3(3), 1-11. Retrieved from https://ejournal3.undip. ac.id/index.php/accounting/article/view/6198/5984

18. Jaafar, M. N., Muhamat, A. A., Alwi, S. F. S., Karim, N. A., \& Rahman, S. binti A. (2018). Determinants of Financial Distress among the Companies Practise Note 17 Listed in Bursa Malaysia. International Journal of Academic Research in Business and Social Sciences, 8(11), 800-811. https://doi.org/10.6007/ijarbss/ v8-i11/4956

19. Jamaludin, M. F., \& Hashim, F. (2017). Corporate governance, institutional characteristics, and director networks in Malaysia. Asian Academy of Management Journal of Accounting and Finance, 13(2), 135-154. https://doi. org/10.21315/aamjaf2017.13.2.7

20. Jostarndt, P., \& Sautner, Z. (2008). Financial distress, corporate control, and management turnover. Journal of Banking and Finance, 32(10), 2188-2204. https://doi.org/10.1016/j.jbankfin.2007.12.040

21. Kamaluddin, A., Ishak, N., \& Mohammed, N. F. (2019).

Financial distress prediction through cash flow ratios analysis. International Journal of Financial Research, 10(3), 63-76. https://doi. org/10.5430/ijfr.v10n3p63

22. Kasmiati, M., \& Santosa, P. W. (2019). The effect of earning information, cash flow componens, firnancing decision, and Stock Return: Empirical Evidence on Indonesia stock exchange. Journal of Economics, Business \& Accountancy Ventura, 22(2), 157-166. Retrieved from https://journal.perbanas.ac.id/index.php/jebav/article/view/1638

23. Kristanti, F., \& Herwany, A. (2017). Corporate Governance, Financial Ratios, Political Risk and Financial Distress: A Survival Analysis. Accounting \& Finance Review, 2(2), 26-34. Retrieved from https://ideas.repec.org/p/gtr/ gatrjs/afr130.html

24. Kumalasari, R. D., Hadiwidjojo, D., \& Indrawati, N. K. (2014).

The Effect of Fundamental Variables and Macro Variables on the Probability of Companies to Suffer Financial Distress: A Study on Textile Companies in BEI. European Journal of Business and Management, 6(34), 275-285. Retrieved from https://www.iiste. org/Journals/index.php/EJBM/ article/view/17165/18016

25. Kurniasanti, A., \& Musdholifah. (2018). Pengaruh Corporate Governance, Rasio Keuangan, Ukuran Perusahaan dan Makroekonomi terhadap Financial Distress. Jurnal Ilmu Manajemen, 6(3), 197-212. Retrieved from https://jurnalmahasiswa.unesa.ac.id/index.php/ jim/article/view/23907

26. Li, M. Y. L., \& Miu, P. (2010). A hybrid bankruptcy prediction model with dynamic loadings on accounting-ratio-based and market-based information: A binary quantile regression approach. Journal of Empirical Finance, 17(4), 818-833. https:// doi.org/10.1016/j.jempfin.2010.04.004

27. Lu, Y., \& Ma, D. (2016). Audit quality and financial distress: Evidence from China. WSEAS Transactions on Business and Economics, 13, 330-340. Retrieved from https://researchspace.auckland.ac.nz/handle/2292/39294

28. Masdupi, E., Tasman, A., \& Davista, A. (2018). The Influence of Liquidity, Leverage and Profitability on Financial
Distress of Listed Manufacturing Companies in Indonesia. Advances in Economics, Business and Management Research, 57, 223-228. https://doi.org/10.2991/ piceeba-18.2018.51

29. Moreno-Bromberg, S., \& Vo, Q. A. (2017). Resolution of financial distress under agency frictions. Journal of Banking and Finance, 82, 40-58. https://doi.org/10.1016/j. jbankfin.2017.05.009

30. Opler, T. C., \& Titman, S. (1994). Financial Distress and Corporate Performance. The Journal of Finance, 49(3), 1015-1040. https:// doi.org/10.2307/2329214

31. Pranowo, K., Achsani, N. A., Manurung, A. H., \& Nuryartono, N. (2010). The dynamics of corporate financial distress in emerging market economy: Empirical evidence from the Indonesian Stock Exchange 20042008. European Journal of Social Sciences, 16(1), 138-149. Retrieved from https://www.researchgate. net/publication/228371540_The_ Dynamics_of_Corporate_Financial_Distress_in_Emerging_Market_Economy_Empirical_Evidence_from_the_Indonesian Stock_Exchange_2004-2008

32. Prasetyo, R. A., \& Fachrurrozie (2016). Analysis of Factors Effecting on The Probability of Financial Distress. Accounting Analysis Journal, 5(4), 370-380. Retrieved from https://journal. unnes.ac.id/sju/index.php/aaj/ article/view/12668

33. Prommin, P., Jumreornvong, S., Jiraporn, P., \& Tong, S. (2016). Liquidity, ownership concentration, corporate governance, and firm value: Evidence from Thailand. Global Finance Journal, 31, 73-87. https:// doi.org/10.1016/j.gf.2016.06.006

34. Purnanandam, A. (2008). Financial distress and corporate risk management: Theory and evidence. Journal of Financial Economics, 87(3), 706-739. https://doi.org/10.1016/j.jfineco.2007.04.003

35. Rahmat, M. M., Iskandar, T. M., \& Saleh, N. M. (2009). Audit committee characteristics 
in financially distressed and non-distressed companies. Managerial Auditing Journal, 24(7), 624-638. https://doi. org/10.1108/02686900910975350

36. Salleh, K., \& Mara, K. U. P. (2019). Audit Report of Financial Distress Companies: Empirical Evidence. International Journal of Business and Economy, 1(2), 1-12. Retrieved from http://myjms.moe. gov.my/index.php/ijbec/article/ view/6994

37. Santosa, P. W. (2010). Longterm Performance Trends Analysis and Managing Expectation for Active Value (Case study PT Indocement Tunggal Prakarsa, Tbk). Finance \& Accounting Journal, 12(02), 94-101. Retrieved from http://jurnalakuntansi.petra.ac.id/index.php/aku/ article/viewFile/18186/18073

38. Santosa, P. W. (2019). Financial Performance, Exchange Rate and Stock Return: Evidence from Manufacturing Sector. Jurnal Manajemen Teknologi, 18(3), 205-217. https://doi.org/10.12695/ jmt.2019.18.3.5

39. Sayidah, N., Assagaf, A., \& Possumah, B. T. (2019). Determinant of state-owned enterprises financial health: Indonesia empirical evidence. Cogent Business and Management, 6(1), 1-15. https://doi.org/10.1080/ 23311975.2019.1600207

40. Senbet, L. W., \& Wang, T. Y. (2012). Corporate Financial Distress and Bankruptcy: A Survey. SSRN Electronic Journal. https://doi.org/10.2139/ ssrn.2034646

41. Shahwan, T. M. (2015). The effects of corporate governance on financial performance and financial distress: evidence from Egypt. Corporate Governance (Bingley), 15(5), 641-662. Retrieved from https://www. researchgate.net/publication/282305602_The_effects_of_ corporate governance on financial_performance_and_financial_ distress_evidence_from_Egypt

42. Soebyakto, B. B., Mukhtaruddin, Relasari, \& Sinulingga, A. (2018). Company characteristics and risk management disclosure: empirical study of manufacturing companies listed on the Indonesia stock exchange. Problems and Perspectives in Management, 16(2), 396-411. https://doi.org/10.21511/ ppm.16(2).2018.36

43. Sutomo, S., Wahyudi, S., \& Pangestuti, I. R. D. (2020). The determinants of capital structure in coal mining industry on the Indonesia Stock Exchange. Investment Management and Financial Innovations, 17(1), 165174. https://doi.org/10.21511/ imfi.17(1).2020.15

44. Tanyi, P. N., \& Smith, D. B. (2015). Busyness, expertise, and financial reporting quality of audit committee chairs and financial experts. Auditing, 34(2), 59-89. https://doi.org/10.2308/ajpt-50929

45. Tinoco, M. H., \& Wilson, N. (2013). Financial distress and bankruptcy prediction among listed companies using accounting, market and macroeconomic variables. International Review of Financial Analysis, 30, 394419. https://doi.org/10.1016/j. irfa.2013.02.013

46. Tirapat, S., \& Nittayagasetwat, A. (1999). An Investigation of Thai Listed Firms' Financial Distress Using Macro and Micro Variables. Multinational Finance Journal, 3(2), 103-125. https://doi. org/10.17578/3-2-2

47. Vivekananda, A., Achsani, N. A., \& Maulana, T. N. A. (2019). Pengaruh Variabel Kinerja Keuangan Perusahaan dan Makroekonomi terhadap Harga Saham Batubara. Jurnal Aplikasi Manajemen Dan Bisnis, 5(3), 347-360. Retrieved from https://journal.ipb.ac.id/index.php/jabm/article/view/21998

48. Vo, D. H., Pham, B. N. V., Ho, C. M., \& McAleer, M. (2019). Corporate Financial Distress of Industry Level Listings in Vietnam. Journal of Risk and Financial Management, 12(4), 155. https://doi.org/10.3390/ jrfm12040155

49. Waqas, H., \& Md-Rus, R. (2018a). Predicting financial distress: Applicability of O-score and logit model for Pakistani firms. Business and Economic Horizons, 14(2),
389-401. https://doi.org/10.15208/ beh.2018.28

50. Waqas, H., \& Md-Rus, R. (2018b) Predicting financial distress: Importance of accounting and firm-specific market variables for Pakistan's listed firms. Cogent Economics and Finance, 6(1), 1-16. https://doi.org/10.1080/23322039. 2018.1545739

51. Whitaker, R. B. (1999). The early stages of financial distress. Journal of Economics and Finance, 23(2), 123-132. https://doi.org/10.1007/ bf02745946 